\title{
Black urine after medicinal foot baths
}

\author{
Liong Rung Liu, Ming-Yuan Huang, Shu-Tien Huang
}

Emergency Department Mackay Memorial Hospital, Taipei, Taiwan

\section{Correspondence to} Dr Liong Rung Liu, liulrh31@hotmail.com

\section{DESCRIPTION}

A 61-year-old man, without previous disease was admitted to our emergency department (ED) due to syncope at home after soaking his feet in a solution containing $50 \%$ of saponated cresol. On physical examination, the patient was lethargic with a strong medicinal smell and brownish discolouration with bullae formation of his bilateral feet (figure 1A), and with otherwise normal vital signs. According to the family, the patient has the habit of soaking his feet in cresol-soap antiseptic solutions with the belief that it will cure his athlete's foot. This occurred with a frequency of three times a week at a time over halfyear. However, prior to this admission to ED, he was unaware of a prolonged soaking time (approximately 5-6h) due to a depressed conscious level. Laboratory evaluation was significantly for the presence of dark urine, and which was progressively cleared over an $8 \mathrm{~h}$ period (figure 1B). Urine level of $\mathrm{p}$-cresol, $\mathrm{m}$-cresol and phenol in this patient were 2608,5391 and $156 \mathrm{mg} / \mathrm{g}$ creatine respectively, at $1 \mathrm{~h}$ postexposure. The diagnosis of cresol intoxication was established. Skin contact with cresol can result in chemical burns, while chronic exposure may cause dark skin discolouration. Following dermal absorption, cresols undergo oxidative metabolism in the liver and are further degraded to dark-coloured substances, which are rapidly eliminated in the urine. Management of cresol poisoning generally includes decontamination and supportive care. ${ }^{1}$ This patient developed no systemic toxicity after the dermal exposure of cresol and was discharged without any sequelae.

\section{Learning points}

- Dermal contact with cresol could also result in systemic poisoning.

- Recognition of characteristic 'black urine' in primary care settings may assist in the diagnosis of cresol poisoning.

- There is no specific antidote for cresol poisoning and the management principle is decontamination and supportive care.

\section{Competing interests None.}

\section{Patient consent Obtained.}

Provenance and peer review Not commissioned; externally peer reviewed.

\section{REFERENCE}

1 Christiansen RG, Klaman JS, Successful treatment of phenol poisoning with charcoal hemoperfusion. Vet Hum Toxicol 1996;38:27-8.
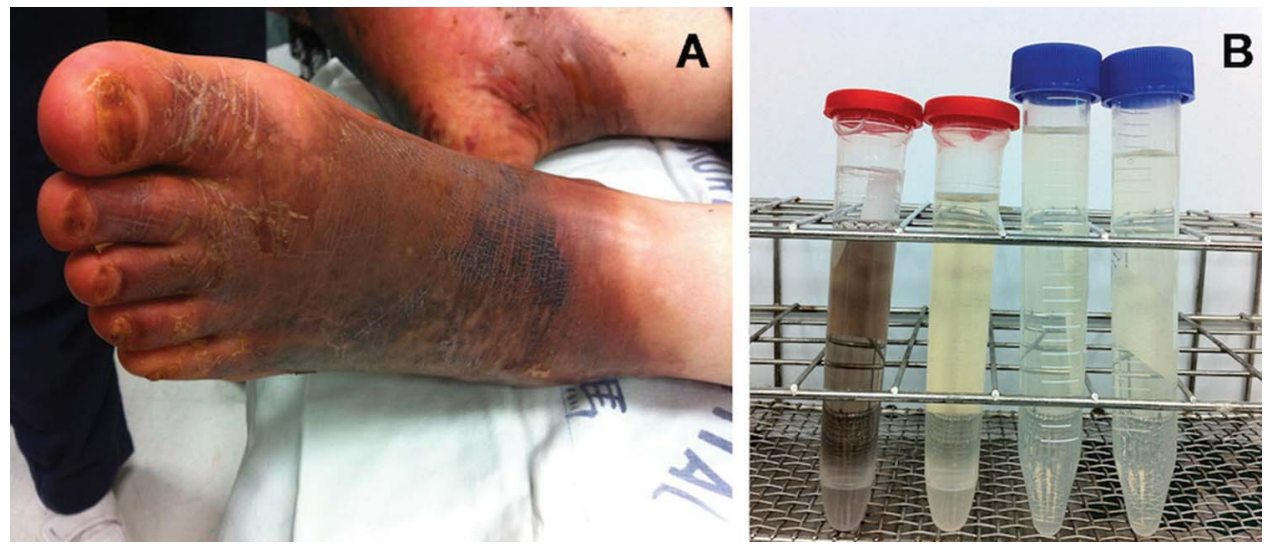

Figure 1 (A) Skin discolouration after foot baths in cresol-soap solutions. (B) Urine colour after the foot baths from black to colourless in $8 \mathrm{~h}$ time.
To cite: Liu $L R$, Huang $M-Y$, Huang S-T. BMJ Case Rep Published online: [please include Day Month Year] doi:10.1136/bcr-2013200771 
Copyright 2013 BMJ Publishing Group. All rights reserved. For permission to reuse any of this content visit http://group.bmj.com/group/rights-licensing/permissions.

BMJ Case Report Fellows may re-use this article for personal use and teaching without any further permission.

Become a Fellow of BMJ Case Reports today and you can:

- Submit as many cases as you like

- Enjoy fast sympathetic peer review and rapid publication of accepted articles

- Access all the published articles

- Re-use any of the published material for personal use and teaching without further permission

For information on Institutional Fellowships contact consortiasales@bmjgroup.com

Visit casereports.bmj.com for more articles like this and to become a Fellow 